\title{
Introduction to the Research Handbook on Cross-Border Bank Resolution
}

\section{Matthias Haentjens and Bob Wessels}

Crisis Management in the Banking Sector, the previous research handbook in this series we edited, was published in 2015. In the preface to that book, we noted that "it has been a huge challenge for all of us to keep pace with the on-going developments in the field of bank insolvency law". Indeed, much has happened since then. Most importantly, the dust of the Global Financial Crisis seems to have settled 10 years after, which was different when we edited and wrote our previous book. Where before and at the earliest stages of the Crisis, few jurisdictions across the globe had a specialist regime for bank insolvencies, many now have introduced ones. These new bank insolvency regimes oftentimes have been inspired by the recommendations of international standard setters such as the Financial Stability Board and the Bank for International Settlements. Consequently, these new regimes tend to share common characteristics, which should be conducive to a smooth resolution of a cross-border operating bank. As a notable example, the legal framework for the recovery and resolution of banks has been harmonised throughout the European Union, while the management of resolution has even been centralized for cross-border operating banks in the Eurozone Member States.

Where our previous book was a collection of papers addressing crisis management of failing banks generally, the present book zooms in on the more specific topic of the restructuring and resolution of failing banks that operate across borders. But as we did with the previous book, also for the present handbook, we have chosen a functional approach. The first chapters take the perspective of the regulatory and economic infrastructure that has been, and should be, put in place for the crossborder resolution of banks. The following chapters take the perspective, first, of topics most relevant from a bank's (own) perspective, and then of those topics relevant from the perspectives of a bank's counterparties. The last four chapters present reports of actual cross-border bank failures as they have happened in the recent past in the EU, US, China and Japan. 
As we note in our concluding chapter, the chapters of this book - all in their own way and perspective - appear to lead to the conclusion that the absence of a global framework still jeopardizes the effectiveness of any resolution of cross-border operating banks. This is specifically worrisome because these banks represent the biggest banks that are the most intricately interconnected with the rest of the financial system, and thus pose the biggest threat to financial stability. Other factors may contribute to this risk, including cyber-related operational risks, privacy and reputational risks, and the recent rise of nationalism and increase of global political instability. A binding global regime for the resolution of banks cannot, therefore, be expected in the near future.

Four steps, we conclude, could be distinguished that should be taken in parallel to address the issue: (i) solutions under private law be found regarding the relationships between the failing bank and its counterparties, both ex-ante and ex-post resolution; (ii) cooperative solutions be adopted by authorities responsible for early intervention and resolution; (iii) (automatic) recognition be established by national authorities, or by the EU, of foreign resolution measures; and (iv) global solutions be found such as the harmonisation of resolution laws and the creation of a supranational authority for cross-border resolution. Ideally, these steps should be taken in parallel as their implementation will enhance legal certainty.

Thus, this Research Handbook on Cross-Border Bank Resolution aims to offer an in-depth review of market conditions and legal rules, current hard law and existing soft law, as well as future developments in this area. We reiterate our gratefulness to a group of 20 outstanding experts (academics, practitioners and legislators) from all over the globe who have contributed to this book. We once again thank the contributors for their efforts in making this book such a valuable source and are grateful for the patience we have demanded from them. Special thanks are due to our doctoral student Shuai Guo, who has done a tremendous editing and drafting job, as well as to the editorial team at Edward Elgar, who have all assisted in making this project a success.

We are confident that also this book delivers cutting-edge material to a worldwide academic and practitioner audience, and increases their understanding and awareness of the complexities of resolving cross-border banks, failing or likely to fail, both at a domestic as well as an international level.

Matthias Haentjens Bob Wessels Leiden, November 2018 